\title{
Irreducible lateral dislocation of patella
}

\author{
George Yerimah, Neil Eisenstein, Robert Turner
}

Department of Trauma and Orthopaedics, Princess Royal Hospital, Telford, Shropshire, UK

\section{Correspondence to} Neil Eisenstein, eisenstein@doctors.org.uk

\section{DESCRIPTION}

A fit and well 21-year-old man received a blow to the medial side of his knee while dancing in a pub. $\mathrm{He}$ became immediately non-weight-bearing and attended the emergency department. On examination, his knee was held in partial flexion and there was a palpable hard mass lateral to the lateral femoral condyle (figure 1). Radiographs demonstrated a lateral patella dislocation (figure 2). Despite giving the patient $20 \mathrm{mg}$ of intravenous morphine, several litres of entonox and $20 \mathrm{mg}$ of midazolam, the emergency department and orthopaedic on-call teams could not reduce the patella. The patient was taken to theatre the next day

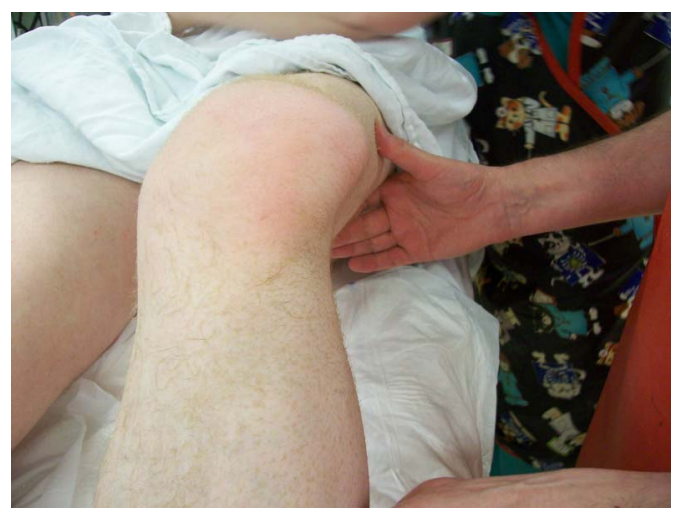

Figure 1 Photograph demonstrating irreducible lateral mass in the left knee.

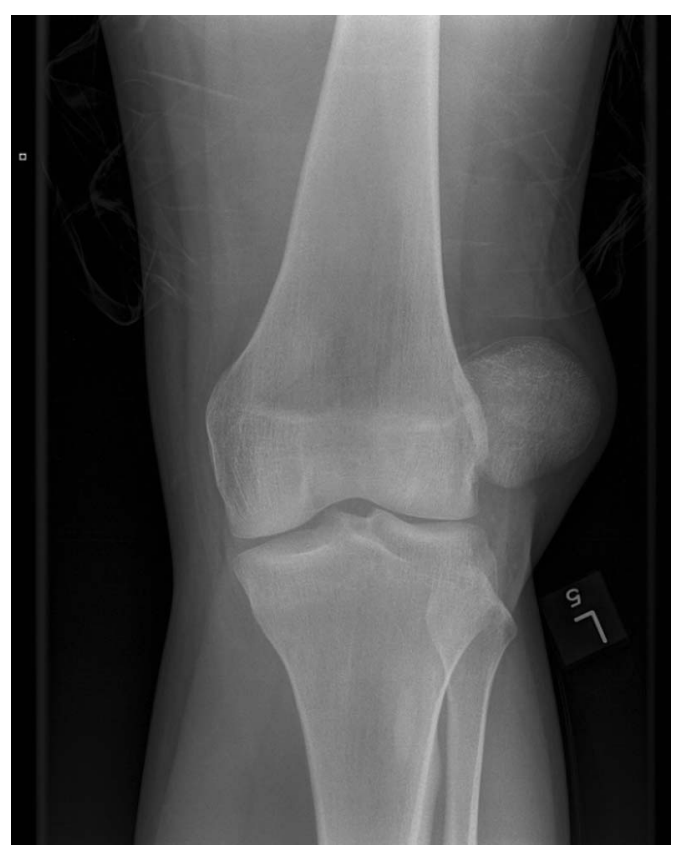

Figure 2 Left knee radiograph demonstrating lateral patella dislocation.

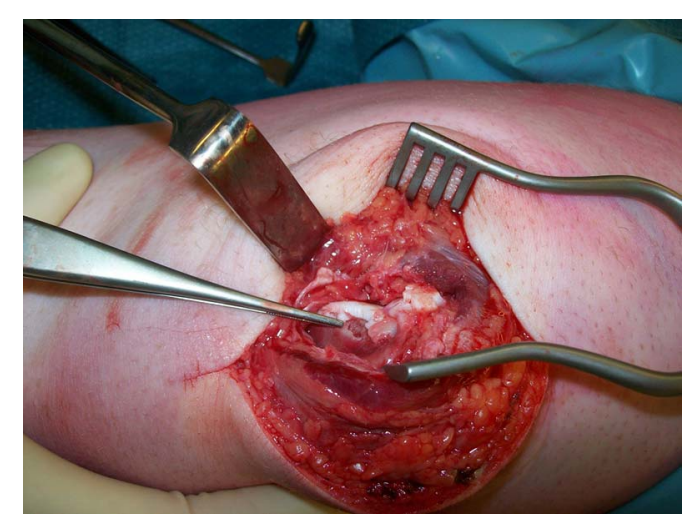

Figure 3 Interoperative photograph showing osteochondral injury to the medial aspect of the patella and associated fragment.

where an attempt at closed reduction under general anaesthesia and a muscle relaxant also failed. A medial parapatellar incision allowed access to the knee joint. Manual exploration of the joint revealed that the patella was impacted against the lateral femoral condyle. Careful manipulation allowed reduction of the patella, demonstrating an osteochondral defect on its medial border (figure 3). This exposed rough surface had 'keyed-in' to the lateral femoral condyle preventing closed reduction. Medial patella-stabilising structures were repaired during closure.

Postoperatively this gentleman was placed into a hinged knee brace locked in full extension. He will start range-of-movement and quadriceps strengthening exercises at 4 weeks postoperation.

This case illustrates that an osteochondral lesion to the patella can cause irreducibility. Previous studies have demonstrated other mechanisms such as lateral femoral condyle impaction fractures ${ }^{12}$ or 'button-holing' of the femur through the medial capsule leading to soft tissue interposition. ${ }^{3}$

\section{Learning points}

- Lateral patella dislocation can cause an osteocondral defect akin to a Hill-Sachs lesion in shoulder dislocations.

- This may make closed reduction difficult or impossible, even with muscle relaxation under general anaesthesia.

- In general, if reduction of any dislocation is proving difficult despite optimal conservative techniques, an open approach may be required.

Contributors Equal contribution from GY and NE. Supervised by RT. Competing interests None. 
Patient consent Obtained.

Provenance and peer review Not commissioned; externally peer reviewed.

\section{REFERENCES}

1 Hackl W. 'Locked lateral patellar dislocation: a rare case of irreducible patellar dislocation requiring open reduction'. Knee Surg Sports Traumatol Arthrosc: Official J. ESSKA 1999:7:352-5.
2 Benjamin J, Percy EC. Irreducible lateral dislocation of the patella. A case report. J Orthop Surg 1984;7:1845-7.

3 Elmali N, Elmali N, Esenkaya I, et al. Delayed reduction of irreducible lateral chronic posterolateral dislocation of the knee with buttonholing of the medial femoral condyle. Eur J Trauma 2005:31:586-9.

Copyright 2013 BMJ Publishing Group. All rights reserved. For permission to reuse any of this content visit http://group.bmj.com/group/rights-licensing/permissions.

BMJ Case Report Fellows may re-use this article for personal use and teaching without any further permission.

Become a Fellow of BMJ Case Reports today and you can:

- Submit as many cases as you like

- Enjoy fast sympathetic peer review and rapid publication of accepted articles

- Access all the published articles

- Re-use any of the published material for personal use and teaching without further permission

For information on Institutional Fellowships contact consortiasales@bmjgroup.com

Visit casereports.bmj.com for more articles like this and to become a Fellow 
